\title{
Micropropagation of New Jersey tea (Ceanothus americanus), sand cherry (Prunus pumila), and sweetbells (Eubotrys racemosa)
}

Jessica D Lubell-Brand and Mark H Brand

ABSTRACT

New Jersey tea (Ceanothus americanus L. [Rhamnaceae]), sand cherry (Prunus pumila L. [Rosaceae]), and sweetbells (Eubotrys racemosa L. [Ericaceae]) are eastern US native shrubs with high potential for expanded landscape use because of their numerous ornamental attributes and adaptability. Micropropagation protocols were developed for these species that produce acceptable shoot multiplication rates, $100 \%$ microcutting rooting, and high-quality liner plants. New Jersey tea is not easily produced from seed or stem cuttings for commercial purposes, but we have demonstrated that micropropagation is a viable method for commercial propagation. In addition, micropropagation can be effectively used to rapidly propagate new superior genotypes of sand cherry and sweetbells.

Lubell-Brand JD, Brand MH. 2021. Micropropagation of New Jersey tea (Ceanothus americanus), sand cherry (Prunus pumila), and sweetbells (Eubotrys racemosa). Native Plants Journal 22(3):355363.

KEY WORDS

tissue culture, native shrubs, landscape plants, micropropagation, Rhamnaceae, Rosaceae, Ericaceae

NOMENCLATURE

USDA NRCS (2020)

Photos by Jessica Lubell-Brand and Mark Brand

This open access article is distributed under the terms of the CC-BY-NC-ND license (http://creative commons.org/licenses/by-nc-nd/4.0) and is freely available online at: http://npj.uwpress.org 
$\mathrm{N}$ ew Jersey tea (Ceanothus americanus L. [Rhamnaceae]), sand cherry (Prunus pumila L. [Rosaceae]), and sweetbells (Eubotrys racemosa L. [Ericaceae]) are eastern US native shrubs with ornamental attributes (Dirr 2011). These plants are adaptable to challenging landscape sites that feature dry infertile soil, full sun exposure, and pedestrian pressure (Hightshoe 1988; Shrestha and Lubell 2015). Despite their ornamental appeal and landscape adaptability, the nursery industry and landscaping public have not taken advantage of these species. They are poised to become more frequently grown and used with increased interest in native landscaping.

Approximately 50 species occur within the genus Ceanothus, but almost all are found in the western half of the US; only C. americanus is found along the East Coast (Dirr 2011). The native range of New Jersey tea extends from Quebec to Minnesota and south to Texas and Florida. New Jersey tea is often found in dry, open woods, woodland edges, pine barrens and in difficult locations characterized by sandy or rocky soils such as banks along roadways (Hightshoe 1988). Plants fix nitrogen through root nodule associations with bacteria from the genus Frankia spp. [Frankiaceae] (Lechevalier and Ruan 1984). New Jersey tea is an important food plant for native insects; for example, the larvae of many butterflies feed on foliage of plants (Wagner 2005). Further, several species of Lepidoptera, some of which are endangered in the northeastern US, feed only on New Jersey tea. New Jersey tea leaves can be used to make tea as the name suggests (Dwelley 1980).

New Jersey tea is a compact, deciduous shrub that reaches $1 \mathrm{~m}$ (3.3 ft) tall (Graves 1952). Its slender, upright stems produce dense, broad mounds (Figure 1). Plants are most known and recognized by their 3 to $5 \mathrm{~cm}(1.2-2.0$ in) long spiked inflorescences, which are composed of small, white, fragrant flowers (Dwelley 1980). Inflorescences are produced on long stalks that originate from the leaf axils at distal ends of shoots. Flowering occurs in mid-June to July (Keeler 1903). The simple, alternate leaves are 5 to $8 \mathrm{~cm}(2.0-3.1$ in) long and narrowly oval with pointed tips. Leaves are dark green in color

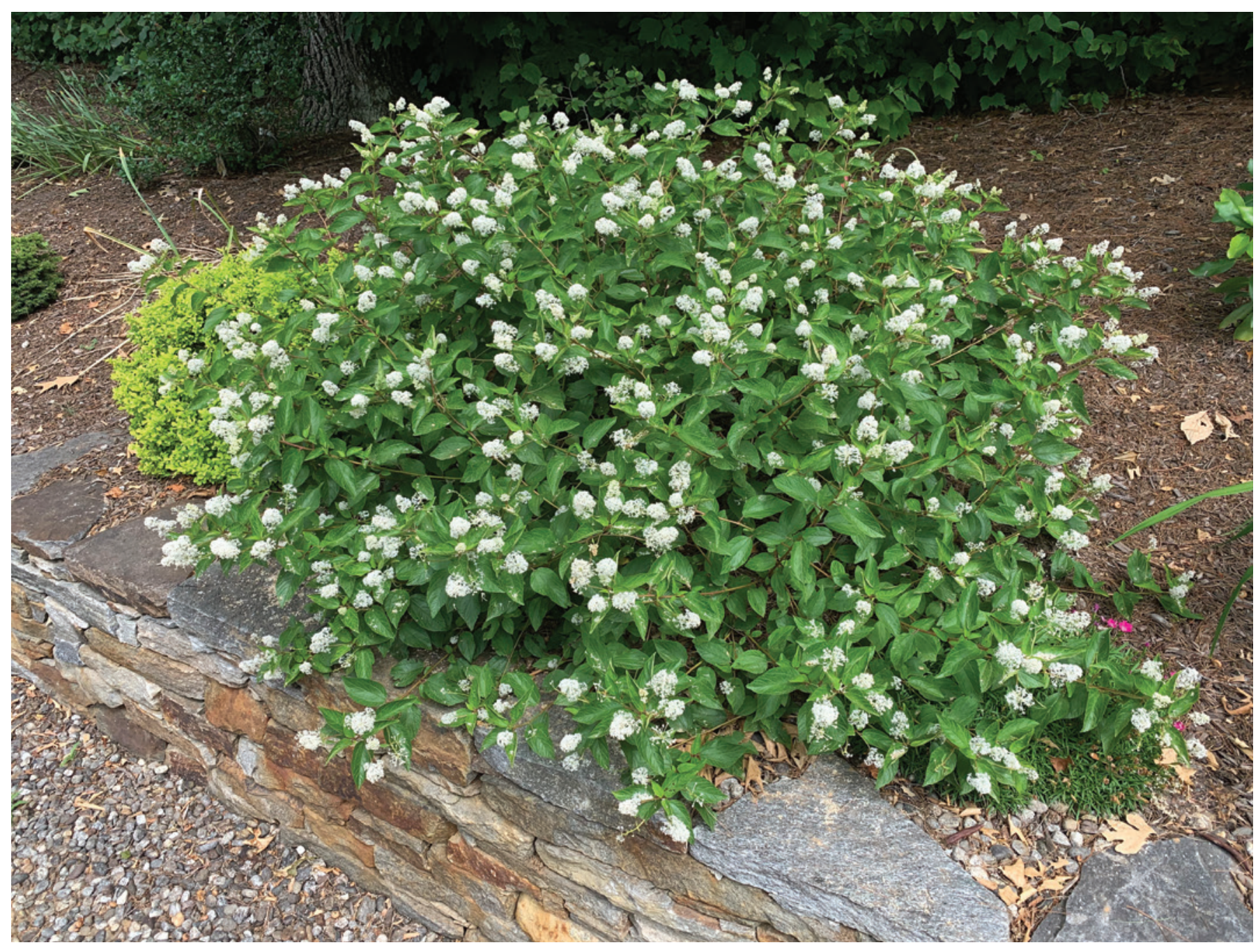

Figure 1. Summer inflorescences and low, mounded habit of New Jersey tea (Ceanothus americanus L. [Rhamnaceae]). 
(Dirr 2011). Fruit capsules are 3-lobed and are initially red but turn black when ripe. New Jersey tea performs best in full sun, but will handle light shade. Well-drained soils are a requirement for New Jersey tea, with established plants tolerating dry soils. It is a good candidate for sites that have sandy, infertile soils that are excessively well-drained; wet areas should be avoided. New Jersey tea can be used in mass plantings on sunny slopes or to stabilize a bank. It is a suitable foundation plant because of its compact size and adaptability to inhospitable conditions. New Jersey tea is an excellent shrub for butterfly gardens. Spring planting into the landscape is recommended for container-grown plants. Plants established in the garden may be pruned for shape at the end of winter dormancy.

Prunus pumila is a complex of closely related subspecies (Rohrer 2000). Depending on the subspecies, the plant can range from a decumbent or prostrate shrub to an upright, rounded, small shrub. Plants will vary in size from $15 \mathrm{~cm}$ to $1 \mathrm{~m}$ (5.9 in to $3.2 \mathrm{ft}$ ) tall (Dwelley 1980), again depending on the subspecies. The native range is eastern Canada and north-

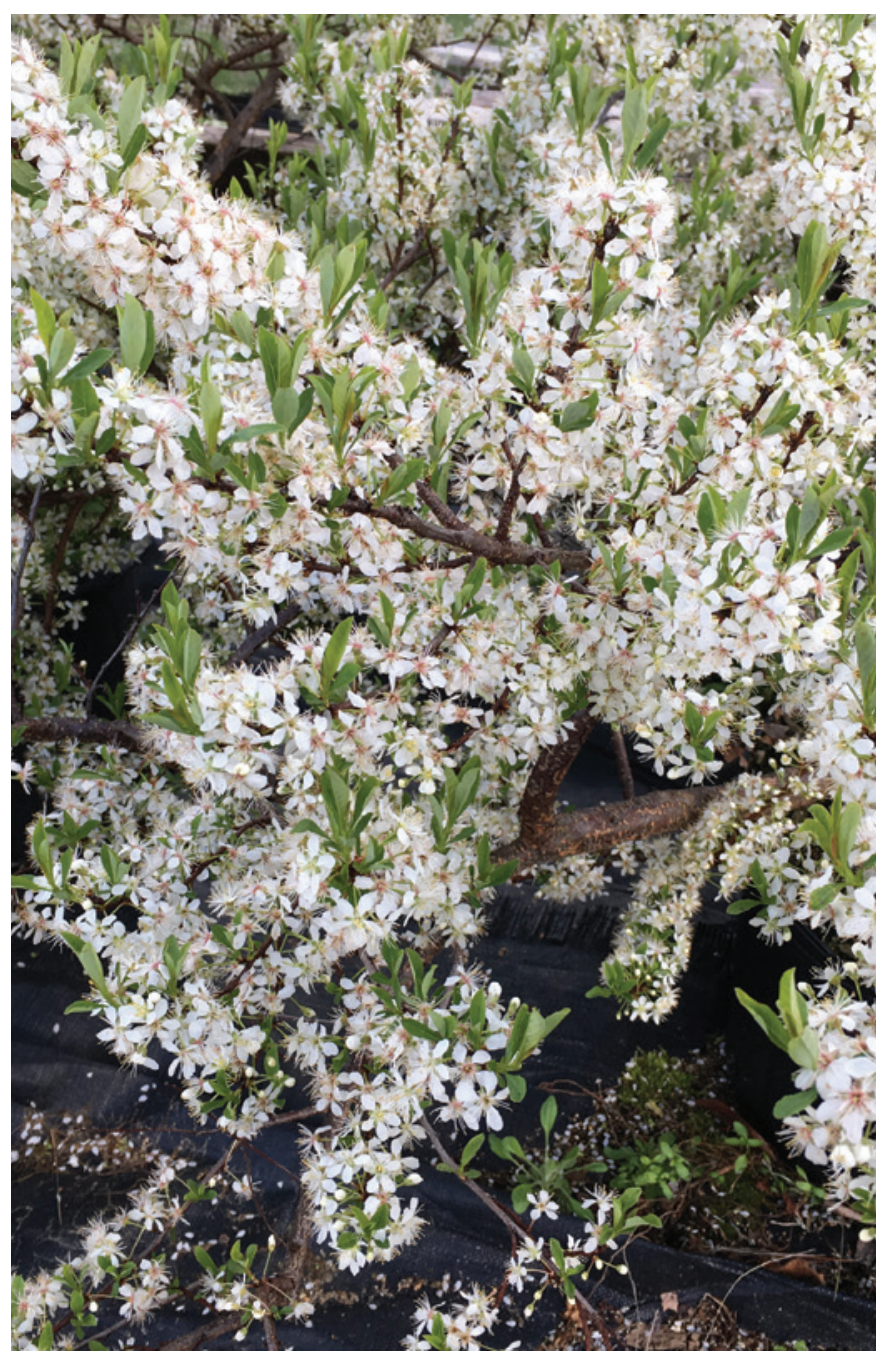

Figure 2. Copious flowers on sand cherry (Prunus pumila L. [Rosaceae]). eastern US (Bragg 2002). Sand cherry is present in all 6 New England states. It naturally grows in a variety of challenging environments including riverbanks, river gravel bars, coastal beaches, meadows and fields, dry ridges or ledges, and sand plains and barrens. Occasionally, it is found growing on sandy roadsides. Plants provide fruit and habitat for birds and small animals as well as nectar and foliage for insects.

Plants produce copious amounts of 5-petal, white flowers in early spring (April to May) as the foliage emerges (Figure 2). The alternate, simple leaves are 2.5 to $8 \mathrm{~cm}$ (1.0-3.1 in) long and 1 to $2 \mathrm{~cm}(0.39-0.79$ in) wide. Emerging new leaves initially have an orange tint and mature to lime green with silver undersides; they turn orange red in fall (Dirr 2011). Plants produce small, black fruits, typical of other wild cherry species.

Sand cherry is widely adaptable to full sun sites and will tolerate dry conditions as well as seasonal flooding. The lowgrowing forms are excellent as a ground cover for difficult sites with full sun or for use at the front edge of the shrub border (Shrestha and Lubell 2015). They also work well in rock gardens, on sunny slopes for bank stabilization, and above retaining walls where shoots will cascade over the wall edge. Upright growing forms work well in any sunny landscape situation requiring a small to medium shrub. Spring-planted trade \#1- or 2-sized container plants become established after one growing season. Established plants are low maintenance and require only occasional removal of old or damaged shoots. Plants may be trimmed to manage plant size.

Sweetbells is a member of the Ericaceae family, which includes many popular garden shrub genera such as Rhododendron, Pieris, Kalmia and Vaccinium (Keeler 1903). The native range begins in southern Massachusetts and extends south along the Atlantic Coast to Florida and then west to Louisiana. It tends to be most abundant in locations close to the coast, and it is found along swamp margins, on hummocks, and in low, sandy woods. As early as the start of the 20th century, sweetbells were recognized by prestigious establishments, such as the Arnold Arboretum, for its beauty as a garden plant, but it has never advanced to garden prominence. Certainly, the same characteristics that were attractive almost a century ago still exist in this plant. There seems to be considerable variation within the species, with some plants producing wider, more attractive broad leaves, some plants producing a heavier flower set, and others maintaining a dense, compact habit. Selections of sweetbells genotypes from the northern portions of its natural range would allow for expanded use of this native across colder parts of the US. Therefore, opportunities exist to make selections with superior traits for landscape use.

Similar in shape and branching to highbush blueberry (Vaccinium corymbosum L. [Ericaceae]), Sweetbells is smaller in stature (1-2 m [3.3-6.6 ft] tall at maturity) and produces 
capsule fruits instead of the fleshy blue fruits of highbush blueberry (Dirr 2011). The alternate, simple leaves are 2 to $8 \mathrm{~cm}(0.79-3.1 \mathrm{in})$ long, oval with a pointed tip, and have a short petiole. New foliage is glossy and emerges with a reddish cast before turning green in summer and then a spectacular scarlet red in fall (Keeler 1903). Some winter interest is derived from the red twig color of new shoots and rose-tinged, naked flower buds. Flowers open in May and are held in 5 to $10 \mathrm{~cm}$ (2.0-3.9 in) long, one-sided terminal racemes (Figure 3). Small, white, urn-shaped flowers resemble highbush blueberry or those of drooping leucothoe (Leucothoe fontanesiana (Steud.) Sleumer [Ericaceae]). Flowers give off a light fragrance that can be detected when close to a sweetbells plant (Graves 1952). The capsule fruit is 5-sectioned and contains many tiny yellow seeds.

Sweetbells is a plant to consider as a replacement for invasive burning bush, because of its excellent red fall color (Figure 4). Furthermore, sweetbells is fairly adaptable to a range of landscape settings and exhibits high deer browse resistance

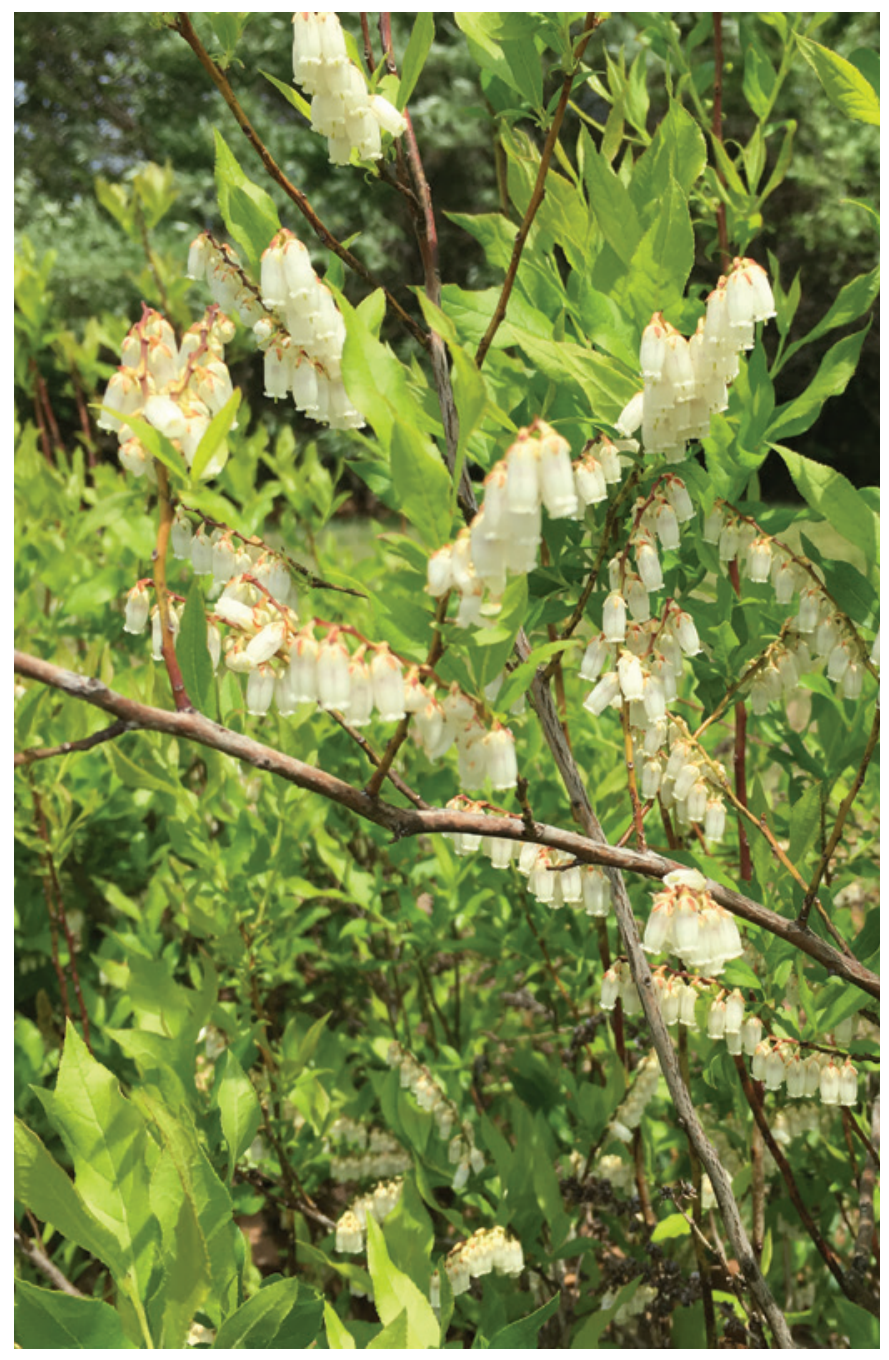

Figure 3. Urn-shaped flowers of sweetbells (Eubotrys racemosa L. [Eri358 caceae]).
(Shrestha and Lubell 2015). Uses include as a foundation plant, screen, in groups, or repeated in a landscape. Plants perform well in full sun to part shade and well-drained soils, but they will tolerate dry situations once established, as well as transiently wet locations (Dirr 2011). Spring-planted trade \#1- or 2-sized container plants will establish after one growing season. Supplemental watering for several weeks following planting is important for good establishment, especially in dry landscape situations.

\section{CURRENT STATE OF PROPAGATION}

New Jersey tea is difficult to propagate from both seed and stem cuttings (Stewart and McGary 2010; Cartabiano and Lubell 2013). A maximum germination rate of $48 \%$ was achieved by exposing seeds for $2 \mathrm{~min}$ to boiling water followed by $60 \mathrm{~d}$ of cold-moist stratification at $4{ }^{\circ} \mathrm{C}\left(39.2^{\circ} \mathrm{F}\right)$ (Stewart and McGary 2010). Stem cutting success of 50\% rooting can be achieved when cuttings are taken in June and treated with 3000 or 8000 ppm IBA (Cartabiano and Lubell 2013). Current reported propagation methods for New Jersey tea fail to meet the $80 \%$ success rate required for largescale commercial nursery production (Cartabiano and Lubell

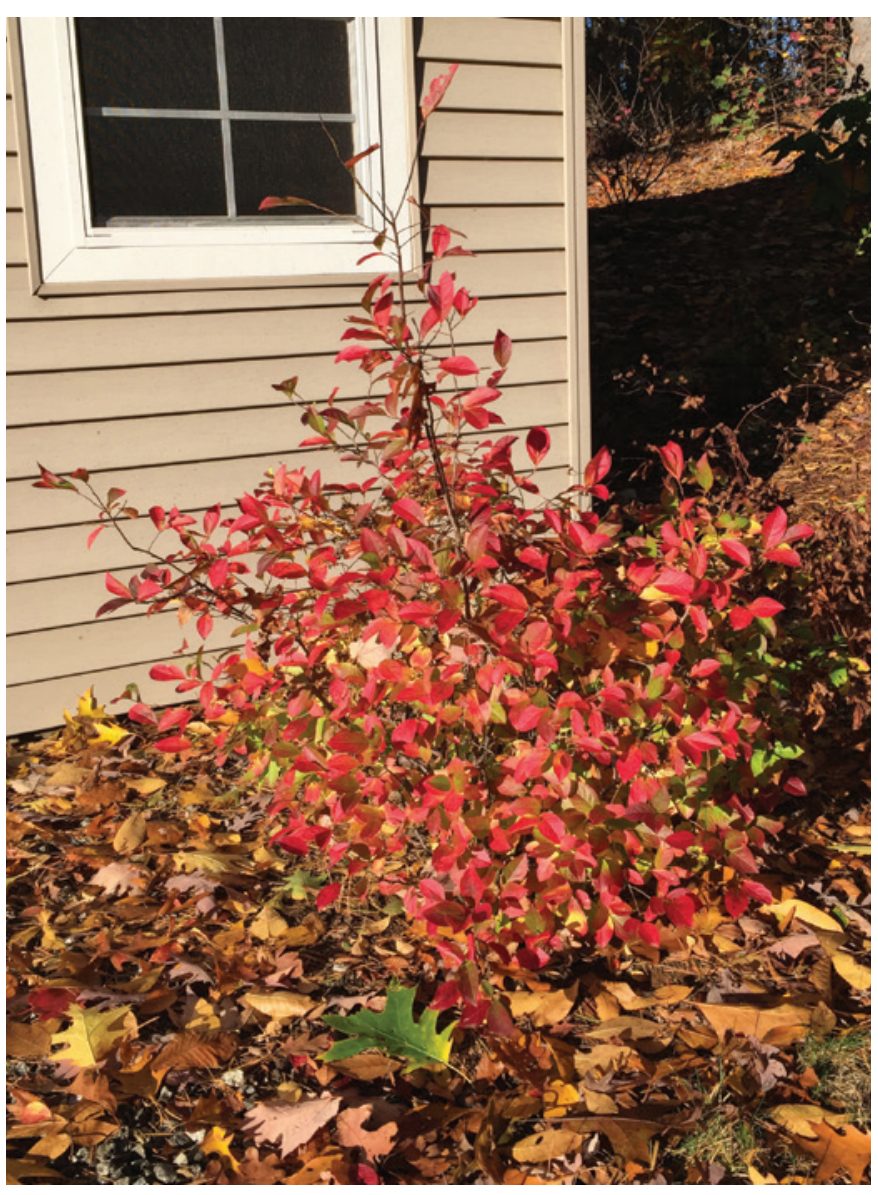

Figure 4. Scarlet red fall foliage color on sweetbells. 
2013). Stem cutting success of greater than $90 \%$ is possible for sand cherry and sweetbells when cuttings are taken in June to July and treated with 1000 to 3000 ppm indole-3-butyric acid (IBA) (Lubell 2013; Lubell and Gardner 2017). Propagation by seed poses a greater challenge for sand cherry and sweetbells, because sand cherries do not consistently produce large fruit crops, and sweetbells have tiny-sized seeds and seedlings, which require enhanced management during cultivation.

Plants produced by micropropagation often demonstrate improved branching structure, enhanced vigor, faster growth, and are disease free compared to plants produced from traditional stem cuttings (Hartmann and others 2010). As new, desirable selections of sand cherry and sweetbells are identified, there will be a need to vegetatively propagate these selections using micropropagation in order to produce enough plants to meet demand for a new plant. For New Jersey tea, micropropagation may be the only way to bring this plant to market in sufficient numbers. Therefore, the objective of this research was to develop micropropagation systems for New Jersey tea, sand cherry, and sweetbells.

\section{MATERIALS AND METHODS}

To initiate shoots in vitro, softwood stems were collected in spring from container-grown plants maintained at the University of Connecticut Floriculture Greenhouses in Storrs, Connecticut. After the leaves were removed, 2 to $3 \mathrm{~cm}(0.79-$ 1.2 in) long stem segments with nodes were disinfected by immersion in a solution of $0.54 \%(\mathrm{w} / \mathrm{v})$ sodium hypochlorite for $15 \mathrm{~min}$ with intermittent agitation, followed by 3 rinses in sterile distilled water. Stem segments were then aseptically trimmed to remove damaged tissue and cultured in $140 \mathrm{ml}$ (4.7 oz) glass baby food jars containing $30 \mathrm{ml}(1.0 \mathrm{oz})$ of medium. New Jersey tea and sweetbells were initially cultured in woody plant (WP) medium (Lloyd and McCown 1980) with $2 \mathrm{mg} / \mathrm{l}$ zeatin ([ZT] before autoclaving), $0.8 \%$ (w/v) agar (MilliporeSigma, St Louis, Missouri), 3\% (w/v) sucrose, and $\mathrm{pH}$ 5.2. Based on observations of shoot performance, the medium was supplemented with iron in the form of Sequestrene 330 at $50 \mathrm{mg} / \mathrm{l}$, and the concentration of zeatin was increased to $4 \mathrm{mg} / \mathrm{l}$. Sand cherry was initially cultured on Murashige and Skoog (MS) medium with vitamins (Murashige and Skoog 1962) with $1 \mathrm{mg} / \mathrm{l}$ benzyladenine (BA), 0.8\% (w/v) agar (MilliporeSigma), $3 \%(\mathrm{w} / \mathrm{v})$ sucrose, and $\mathrm{pH}$ 5.7. Cultures were maintained at $25^{\circ} \mathrm{C}\left(77^{\circ} \mathrm{F}\right)$ and $16 \mathrm{~h}$ photoperiod provided by cool-white fluorescent lamps at an intensity of $40 \mu \mathrm{mol} / \mathrm{m} / \mathrm{s}$.

In vitro multiplied shoots for all 3 species were cut into approximately $2 \mathrm{~cm}$ (0.79 in) long microcuttings, dipped in talc-based IBA rooting hormone at 1000 ppm (Hormodin \#1 [OHP Inc, Bluffton, South Carolina]), and stuck vertically in $600 \mathrm{ml}(20 \mathrm{oz})$ clear plastic salad trays with lids containing $200 \mathrm{ml}(0.07 \mathrm{oz})$ of medium composed of 1 part Canadian sphagnum peat moss (Fafard Inc, Agawam, Massachusetts) and 1 part horticultural grade vermiculite (Whittmore Company, Lawrence, Massachusetts). Trays were maintained at $22.2^{\circ} \mathrm{C}\left(72^{\circ} \mathrm{F}\right)$ under long days $(16 \mathrm{~h})$ with cool-white fluorescent light at $30 \mu \mathrm{mol} \mathrm{m} \mathrm{m}^{-2}$. Microcuttings rooted in $4 \mathrm{wk}$ and initiated new shoot growth. Rooted microcuttings were acclimated to greenhouse conditions by gradually decreasing atmospheric relative humidity around the microcuttings and gradually increasing light levels. This process was accomplished by melting 6 holes $(0.5 \mathrm{~cm}$ [0.20 in] $)$ in the salad tray lids, and then $1 \mathrm{wk}$ later, melting 6 more holes into the lids. After $7 \mathrm{~d}$ with 12 holes in the lid, rooted microcuttings were potted to 96-plug trays, which were covered with clear plastic domes to maintain humidity. Covered plug trays were placed in the greenhouse at $21.1^{\circ} \mathrm{C}\left(70{ }^{\circ} \mathrm{F}\right)$ under $70 \%$ shade for $2 \mathrm{wk}$. Soon after, and during a period of cloudy weather, domes were removed and microcuttings were exposed to fulllight greenhouse conditions. After 6 wk in 96-plug trays, liner plants were potted into $106 \mathrm{ml}(3.5 \mathrm{oz})$ square pots filled with medium composed of 4 parts aged pine bark (Fafard Inc), 2 parts Canadian sphagnum peat moss (Fafard Inc), and 1 part sand (particles 0.05-2 mm diameter, by volume). During the first growing season, plants were provided weekly with 200 ppm soluble 20N:8.74P:16.6K fertilizer (Peters 20-20-20 Fertilizer; ICL-SF, Summerville, South Carolina).

\section{RESULTS AND DISCUSSION}

In vitro shoots of New Jersey tea were initiated on WP medium (Figure 5A), as opposed to MS medium, because we thought this plant would prefer the lower salt formulation of $\mathrm{WP}$, since it is frequently found growing on infertile soils. Cultures established well on WP medium containing $2 \mathrm{mg} / \mathrm{l} \mathrm{ZT}$; however, multiplication and shoot growth rates were slow. We evaluated shoot growth on WP medium containing either $4 \mathrm{mg} / \mathrm{l} \mathrm{ZT}$ or $2 \mathrm{mg} / \mathrm{l} \mathrm{BA}$ in an attempt to improve culture performance. We observed that doubling the ZT increased shoot growth and shoot multiplication rate the most. Supplementation of WP medium with $50 \mathrm{mg} / \mathrm{l}$ iron in the form of Sequestrene 330 eliminated interveinal chlorosis of in vitro shoots. Shoots growing on our optimized medium (Table 1; Figure $5 B)$ can be expected to multiply at a rate of $2 \times$ when shoots are subcultured every $21 \mathrm{~d}$. In vitro shoot growth will slow down and fail if shoots are subcultured beyond the 21-d cycle. After approximately 6 mo in culture, growth had slowed, and they demonstrated reduced vigor. We found that in vitro shoot growth and vigor could be restored by providing cultures with 3 mo of chilling at 3.5 to $4.5^{\circ} \mathrm{C}\left(38-40^{\circ} \mathrm{F}\right)$.

In vitro shoots of sand cherry initiated on $\mathrm{MS}$ medium containing BA multiplied and grew vigorously. This finding was not surprising to us, since many rosaceous plants perform well in vitro and are routinely micropropagated for 


\section{TABLE 1}

Micropropagation medium, shoot multiplication rate, and subculture frequency for in vitro cultures of New Jersey tea, sand cherry, and sweetbells.

\begin{tabular}{lcccccc} 
Species & Medium type $^{z}$ & Hormone $^{y}$ & Sequestrene 330 & pH & Shoot multiplication rate & Subculture frequency (d) \\
\hline New Jersey tea & WP & $4 \mathrm{mg} / \mathrm{I} \mathrm{ZT}$ & $50 \mathrm{mg} / \mathrm{l}$ & 5.2 & $2 \times$ & 21 \\
\hline Sand cherry & MS & $0.5 \mathrm{mg} / \mathrm{l} \mathrm{BA}$ & - & 5.7 & $8 \times$ & $28-35$ \\
\hline Sweetbells & WP & $4 \mathrm{mg} / \mathrm{I} \mathrm{ZT}$ & $50 \mathrm{mg} / \mathrm{l}$ & 5.2 & $3 \times$ & $35-42$ \\
\hline
\end{tabular}

${ }^{2}$ Medium type abbreviations: Woody plant (WP), Murashige and Skoog with vitamins (MS).

${ }^{y}$ Hormone abbreviations: zeatin (ZT), benzyladenine (BA).
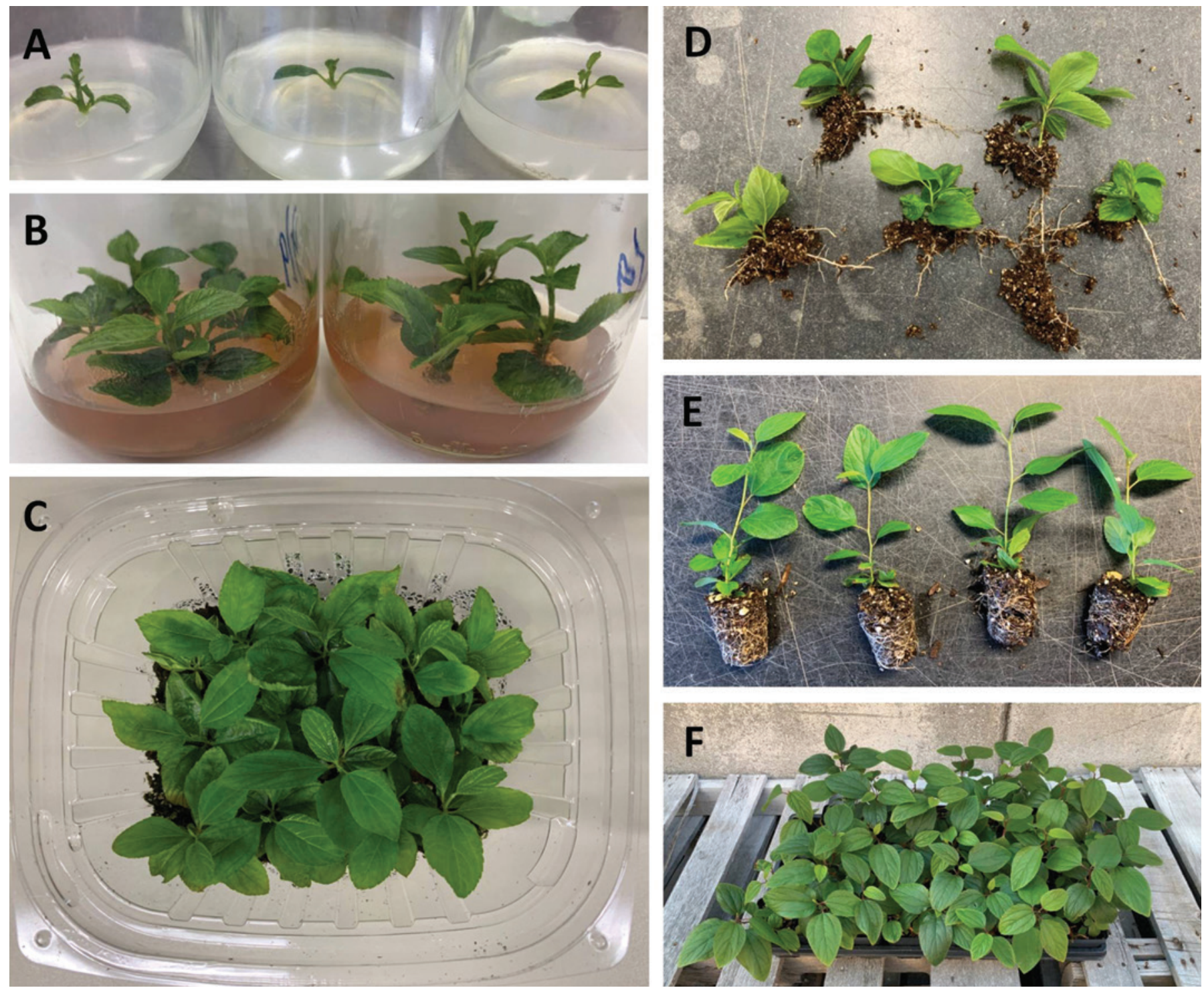

Figure 5. Micropropagation of New Jersey tea: recently initiated shoots (A); proliferating shoots (B); rooted and acclimated microcuttings ready for transfer to the greenhouse (C); rooted microcuttings exhibiting a well-developed, coarse, white root system (D); fully acclimated growing plantlets from a 96-plug tray in the greenhouse ready for up-potting and transfer to outdoor conditions (E); high-quality liner plants in 106-ml pots $(F)$.

the nursery trade using MS medium supplemented with BA (Hartmann and others 2010). We found that lowering the allowed for better shoot expansion and leaf lamina development. The higher initial level of BA was useful during culture initiation, but eventually stimulated excessive multiplication 

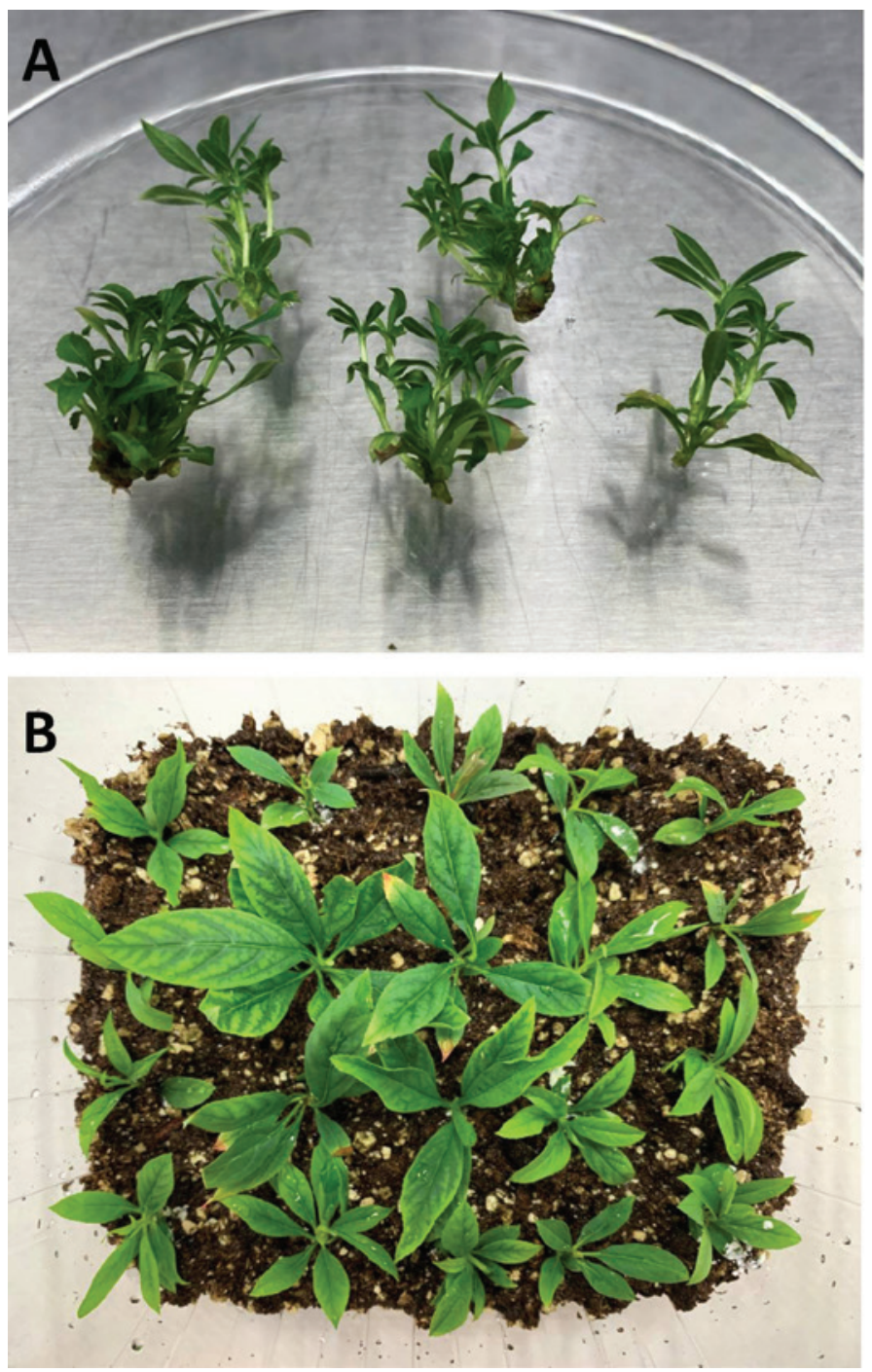
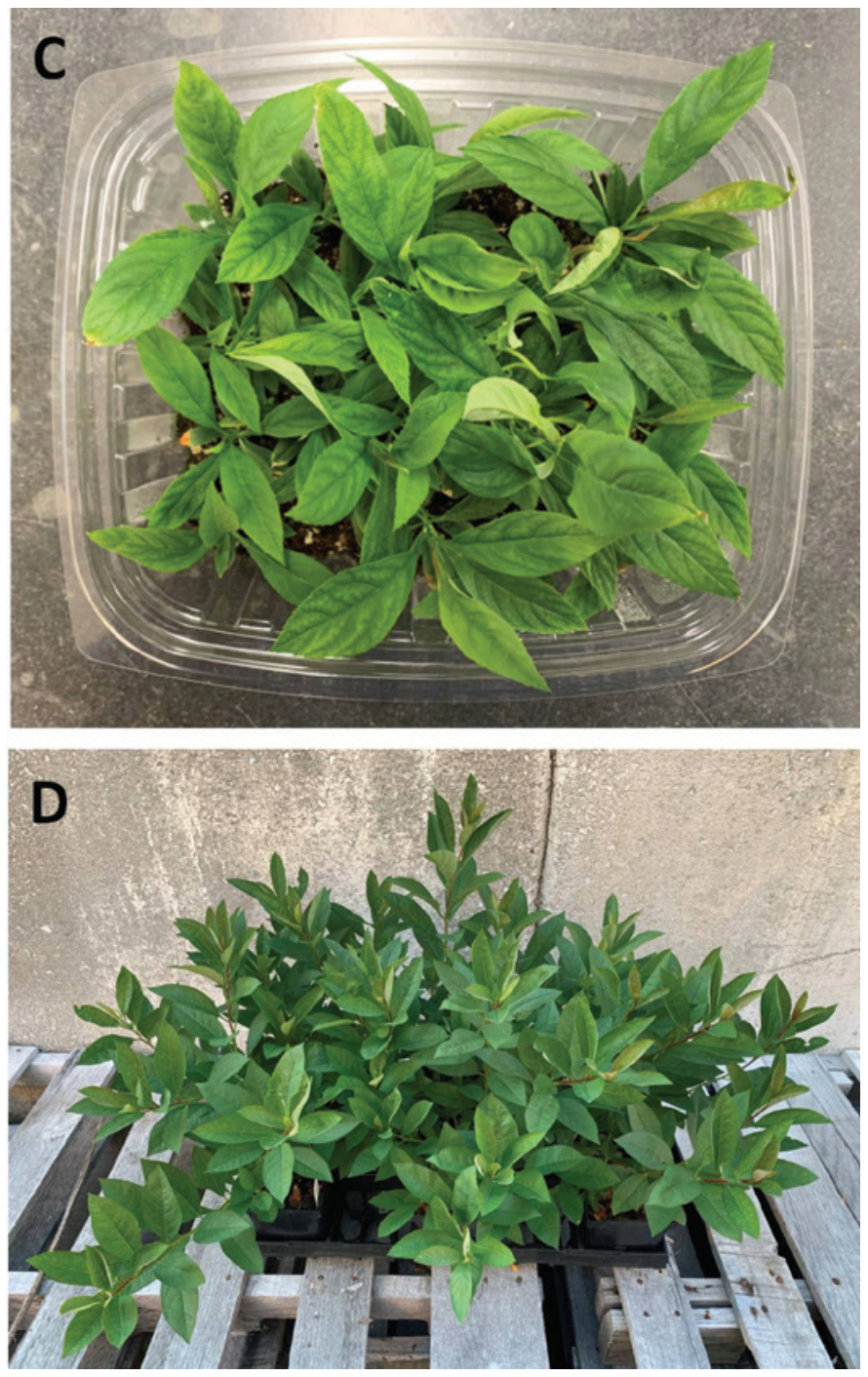

Figure 6. Micropropagation of sand cherry: proliferating in vitro shoots (A); microcuttings at time of sticking (B); rooted and acclimated microcuttings ready for transfer to the greenhouse (C); high-quality liner plants in 307-ml pots (D).

of shoots, which were shorter than desirable and exhibited poor leaf lamina development. In vitro shoots of sand cherry multiply at a high rate of at least $8 \times$ and shoots can be maintained for 28 to $35 \mathrm{~d}$ before subculturing without negatively impacting subsequent culture growth (Table 1; Figure 6A).

Cultures of sweetbells were initiated on WP medium instead of MS medium, because this plant belongs to the Ericaceae family and most ericaceous plants grown in vitro perform better on culture medium with lower inorganic nutrient content salts than on MS medium (Hartmann and others 2010). Shoots grew well on WP medium with $2 \mathrm{mg} / \mathrm{l} \mathrm{ZT}$; however, growth and multiplication rates were improved when the amount of ZT was increased to $4 \mathrm{mg} / \mathrm{l}$. Supplementation of the medium with $50 \mathrm{mg} / \mathrm{l}$ Sequestrene improved the foliage color appearance from uneven, pale green to uniform, medium to dark green. A $3 \times$ multiplication rate can be expected for sweetbells growing on our optimized medium when shoots are subcultured every 35 to $42 \mathrm{~d}$ (Table 1; Figure 7A).
For all 3 species, microcuttings were easily rooted ex vitro in salad trays (100\% rooting), and rooting can be expected in 3 to 4 wk (Figures 5C, 6B, 6C, 7B, 7C). New Jersey tea produced moderately thick, coarse white roots (Figure 5D). Sand cherry roots were white with a pink tinge and were fairly large, but not as large as New Jersey tea. Sweetbells produced a fine root system typical of those seen on ericaceous plants such as blueberry or rhododendron (Figure 7D). Acclimation of rooted microcuttings to greenhouse conditions was easily accomplished using the 2 -wk venting process described previously. New shoot growth began rapidly for all species after potting rooted microcuttings in 50-cell plug trays and applying fertilizer. Rooted microcuttings were acclimated into the greenhouse in early spring. This timing is important to provide the young micropropagated plantlets a long photoperiod, strong irradiance, and warm temperatures. Plantlets acclimated in fall or winter would be more challenging to grow out strongly and would likely enter summer dormancy. 

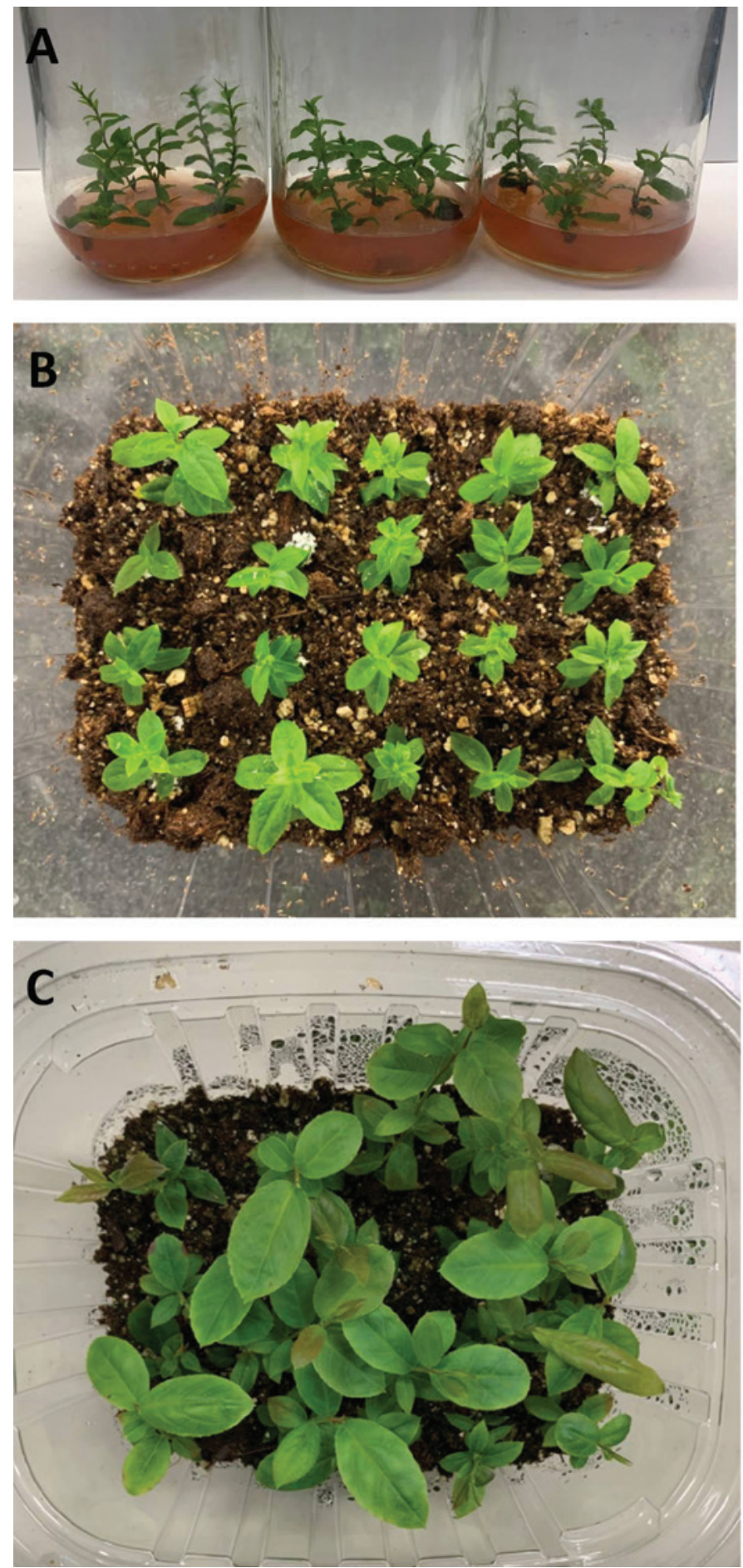
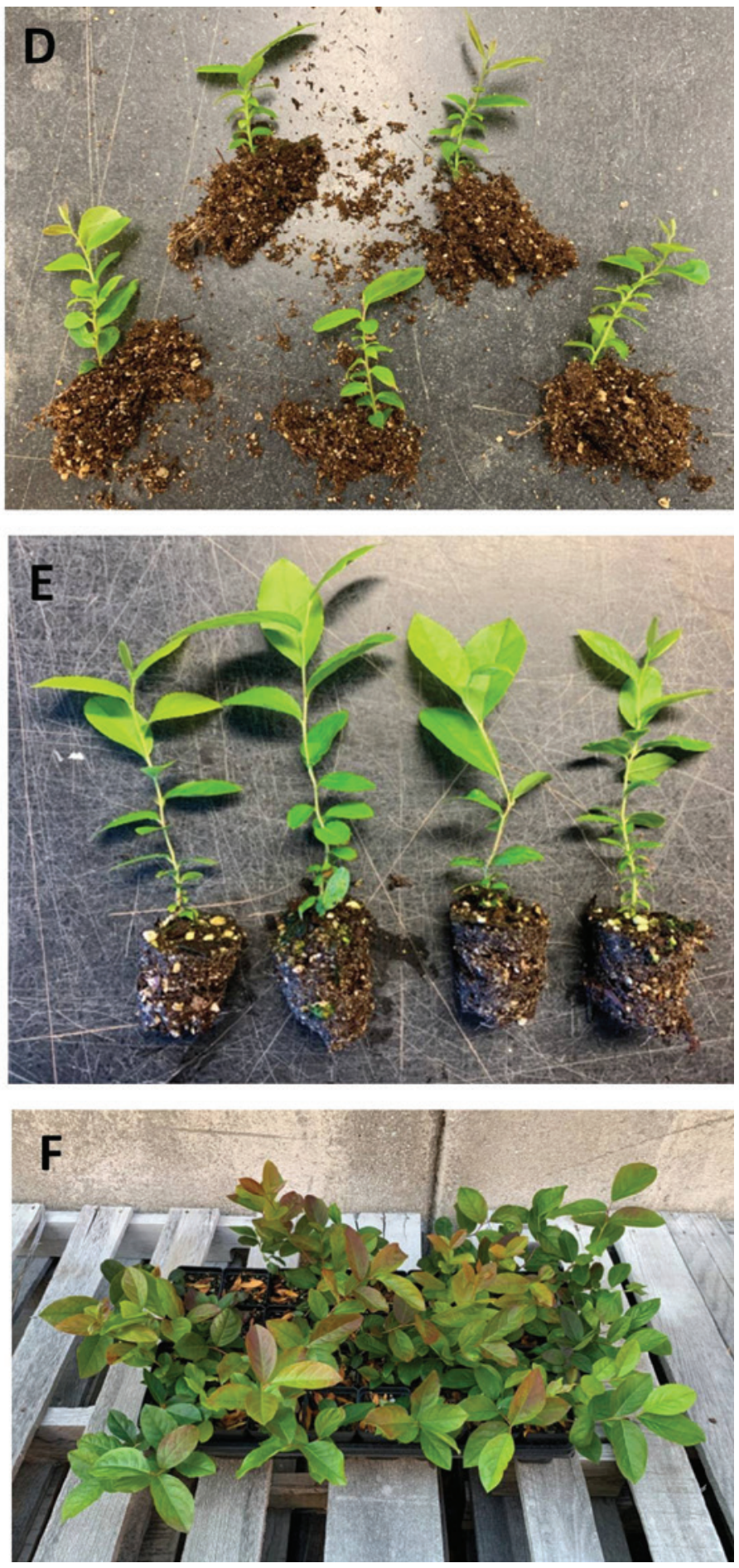

Figure 7. Micropropagation of sweetbells: proliferating shoots (A); microcuttings at time of sticking (B); rooted and acclimated microcuttings ready for transfer to the greenhouse (C); rooted microcuttings exhibiting a fine root system (D); fully acclimated plantlets from a 96-plug tray in the greenhouse ready for up-potting and transfer to outdoor conditions (E); high-quality liner plants in 106-ml pots (F).

The tissue culture protocol described here for New Jersey tea represents a significant improvement in propagation for this species. Micropropagated shoots rooted at $100 \%$ success, which is twice the rate that can be expected from tradi- cherry and sweetbells may be propagated using traditional softwood stem cuttings, the micropropagation protocol we developed will be useful for growers looking to rapidly produce large numbers of disease-free plants of improved horticultural selections. 


\section{ACKNOWLEDGMENT}

This work was supported by the USDA National Institute of Food and Agriculture, Hatch project, accession number 1020832 .

\section{REFERENCES}

Bragg DC. 2002. Prunus pumila L. In: Francis JK, editor. Wildland shrubs of the United States and its territories: thamnic descriptions. USDA Forest Service General Technical IITF-WB-1. p 1-3. Washington (DC).

Cartabiano JA, Lubell JD. 2013. Propagation of four underused native species from softwood cuttings. HortScience 48:1018-1020.

Dirr MA. 2011. Manual of woody landscape plants. 6th ed. Champaign (IL): Stipes Publishing. 1325 p.

Dwelley MJ. 1980. Trees and shrubs of New England. Camden (ME): Down East Books. 276 p.

Graves AH. 1952. Illustrated guide to trees and shrubs. Wallingford (CT): Published by the author. $240 p$.

Hartmann HT, Kester DE, Davies FT, Geneve RL. 2010. Hartmann and Kester's plant propagation: principles and practices. 8th ed. London (UK): Pearson. 928 p.

Hightshoe GL. 1988. Native trees, shrubs and vines for urban and rural America. New York (NY): Wiley. $819 p$.

Keeler HL. 1903. Our northern shrubs. New York (NY): Charles Scribner's Sons. $521 \mathrm{p}$.

Lechevalier MP, Ruan J. 1984. Physiology and chemical diversity of Frankia spp. isolated from nodules of Comptonia peregrina (L.) Coult. and Ceanothus americanus L. Plant and Soil 78:15-22.

Lloyd G, McCown B. 1980. Commercially-feasible micropropagation of mountain laurel, Kalmia latifolia, by use of shoot tip culture. Proceedings of the International Plant Propagators' Society 30:421427.

Lubell JD. 2013. Evaluating landscape performance of six native shrubs as alternatives to invasive exotics. HortTechnology 23:119_ 125.

Lubell JD, Gardner JAG. 2017. Production of three eastern US native shrubs: effects of auxin concentration on rooting and shade level on container plant growth. HortTechnology 27:375-381.

Murashige T, Skoog F. 1962. A revised medium for rapid growth and bio assays with tobacco tissue cultures. Physiologia Plantarum 15:473-497.

Rohrer JR. 2000. The sand cherry in Wisconsin and neighboring states. Michigan Botanist 39:59-69.

Shrestha P, Lubell JD. 2015. Suitability of eight northeastern U.S. native shrubs as replacements for invasive plants in a difficult landscape site with white-tailed deer pressure. HortTechnology 25:171-176.

Stewart JR, McGary I. 2010. Brief exposure to boiling water combined with cold-moist stratification enhances seed germination of New Jersey tea. HortTechnology 20:623-625.

[USDA NRCS] USDA Natural Resources Conservation Service. 2020. The PLANTS database. URL: http://plants.usda.gov (accessed 2020). Greensboro (NC): National Plant Data Team.
Wagner DL. 2005. Caterpillars of eastern North America. Princeton (NJ): Princeton University Press. 512 p.

\section{AUTHOR INFORMATION}

\section{Jessica D Lubell-Brand}

Associate Professor

jessica.lubell@uconn.edu

\section{Mark H Brand}

Professor

mark.brand@uconn.edu

Department of Plant Science and Landscape

Architecture

University of Connecticut

1376 Storrs Road, Unit-4067

Storrs, CT 06279

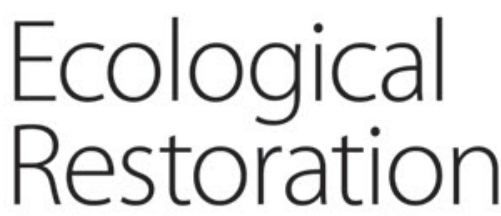

The Original Restoration Publication

Edited by Steven N. Handel | er.uwpress.org ISSN I522-4740, e-ISSN 1543-4079 | 4/year

A forum for people advancing the science and practice of restoration ecology.

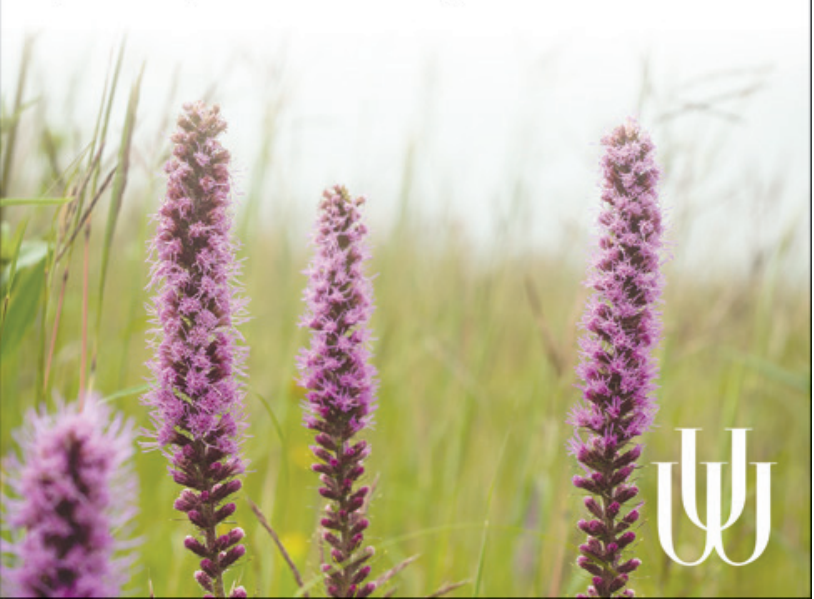

